\title{
ORGANISATORISCHE INPASSING VAN INFORMATIESYSTEMEN IN ONDERNEMINGEN
}

\author{
door Dr. T. Tieleman
}

\section{Inleiding}

Op 21 april 1977 verdedigde ik aan de Technische Hogeschool Twente mijn proefschrift, getiteld „Organisatorische aspecten van management informatiesystemen".

De uitnodiging van de redactie om de betekenis van deze studie in een kort artikel uiteen te zetten heb ik bewust even laten liggen, enerzijds om zelf wat af. stand te kunnen nemen, anderzijds om de reacties op mijn proefschrift op mij te laten inwerken. Gaarne voldoe ik nu aan het redactionele verzoek.

\section{Informatiesystemen bieden ondersteuning}

Centraal in de studie staat de relatie tussen de informatiesystemen en de organisatie waarbinnen ze moeten functioneren. Het gaat uiteindelijk om de ondersteuning die informatiesystemen kunnen bieden, vooral in gecompliceerde organisaties. Kortom, welke eisen kunnen gesteld worden aan de organisatorische inpassing van informatiesystemen in b.v. ondernemingen. Onder een informatiesysteem wordt verstaan, ,een geheel van mensen, middelen en procedures dat de als invoer verkregen geformaliseerde informatie op zodanige wijze kan verwerken dat de als uitvoer beschikbare geformaliseerde informatie toegespitst is op het goed functioneren van een logistiek proces of van een managementproces".

Uit deze definitie blijkt dat daaronder zowel geautomatiseerde als ook niet-ge. automatiseerde informatiesystemen vallen. Kenmerkend voor informatiesystemen is niet het al of niet geautomatiseerd zijn maar de ondersteuning die ze in de praktijk kunnen bieden.

Om die ondersteuning te kunnen bieden dienen informatiesystemen toegespitst te zijn op de processen die zich in de praktijk van de organisaties voltrekken. In dit verband worden twee soorten processen onderscheiden: logistieke processen en managementsprocessen.

\section{Ondersteuning van logistieke processen}

Onder een logistiek proces wordt verstaan „een stapsgewijze opeenvolging van gebeurtenissen die plaatsvinden om uit aangewende middelen goederen en diensten te produceren".

Logistiek is een begrip dat in de Nederlandse taal voornamelijk gebruikt wordt om bepaalde militaire operaties aan te duiden. Van Dale verstaat onder logistiek dan ook ,alle voorbereidingen en handelingen die nodig zijn om de troepen op de meest doeltreffende wijze van goederen en voorraden te voorzien en onder de meest gunstige omstandigheden te doen strijden". Winkler Prins Encyclopedie 
betrekt hierin ook het personeel wanneer gesteld wordt dat dit zich uitstrekt over „het hele gebied van de planning en uitvoering van de verschaffing van middelen, i.c. personeel, materieel, faciliteiten en diensten".

Bij logistieke processen gaat het dus om de planning en de uitvoering van de fysieke activiteiten, die nodig zijn om uit aangewende middelen uiteindelijk goederen en diensten te produceren. Deze logistieke processen worden ondersteund door logistieke informatiesystemen. Kenmerkend voor deze logistieke informatiesystemen is, dat deze uitdrukkelijk toegespitst zijn op de logistieke processen, die ze moeten ondersteunen. Dat kan in hoge mate bevorderd worden door het aanwijzen van een systeemmanager, die voor de bouw van en later ook de aanpas. singen binnen dit logistieke informatiesysteem (LIS) verantwoordelijk is. Hij functioneert als brug tussen de gebruikers enerzijds en de bouwers/aanpassers ander. zijds.

De toepassing van een LIS op een logistiek proces kan evenwel de waarde van de uitvoer van het LIS voor hogere managementposities verminderen. In de vol. gende paragraaf kom ik daarop terug.

\section{Ondersteuning van managementsprocessen}

Onder een managementsproces wordt verstaan de „uitoefening van de managementsfuncties door één managementpositie (d.w.z. òf een individuele manager òf een managementteam), hetzij met betrekking tot de organisatie als geheel, hetzij met betrekking tot een onderdeel daarvan". Het gaat dus hier in wezen om de activiteiten van het management op de wat hogere niveaus in de organisatie. Een management informatiesysteem is dan ook gericht „op het goed functioneren van één bepaalde managementpositie".

De verschillen tussen logistieke informatiesystemen (LI-systemen) en management informatiesystemen (MI-systemen) kunnen als volgt worden samengevat:

\section{LI-systemen}

- dienen ter ondersteuning van één logistiek proces

- zijn gekoppeld met de stapsgewijze opeenvolging van gebeurtenissen binnen één logistiek proces; kunnen op meerdere afdelingen betrekking hebben

- worden gebouwd met als uitgangs. punt de elementaire gegevens (bottom-up approach)
MI-systemen

- dienen ter ondersteuning van één managementsproces

- zijn toegespitst op één managementpositie en wel één van zodanig niveau dat deze verantwoordelijk is voor meerdere logistieke processen

- worden gebouwd vanuit het stand punt van de managementpositie (top-down approach)

Voor beide categorieën informatiesystemen geldt dat ieder afzonderlijk informatiesysteem door één verantwoordelijke man beheerd moet worden. Voor een LIS is dat - zoals we reeds gezien hebben - een systeemmanager, voor een management informatiesysteem (MIS) is dat een informatiemanager. 


\section{Informatiemanager}

De functionaris, die verantwoordelijk is voor het goed functioneren van een MIS is de informatiemanager. Hij moet zich steeds van de kenmerken van „zijn” MIS goed bewust zijn. Deze kenmerken zijn:

- gericht op één managementpositie

- wordt gebouwd van „top” naar „bottom”

- ondersteunt met name de managementfuncties ,planning" en "control”

- geeft een compleet beeld (maar géén gedetailleerd beeld!) van de managementverantwoordelijkheid, met nadruk op de „key factors for success”

- heeft betrekking op (een deel van) de onderneming, maar ook op omgeving daarvan, voorzover deze relevant is voor de functioneringsmogelijkheden van de onderneming

Uit het voorgaande moge duidelijk geworden zijn dat een MIS voor een belang. rijk deel gevoed wordt met geaggregeerde informatie uit veel LI-systemen. Binnen die LI-systemen ligt echter de inzet van computers méér voor de hand dan binnen het MIS. Immers, binnen LI-systemen is veel vaker sprake van massale gegevensverwerking dan binnen een MIS.

In een MIS komt zeer veel informatie uit verschillende bronnen van binnen èn van buiten de onderneming samen. Voor ieder deeltje daarvan is een bepaalde functionaris in die onderneming verantwoordelijk. Het is zaak deze verantwoordelijkheid niet te verdoezelen maar deze juist expliciet tot uitdrukking te laten ko. men, óók in het MIS. De informatiemanager heeft ten deze een stimulerende en coördinerende taak. Hij moet zorgen voor goede contacten met allen die de in. voer in het MIS verzorgen; bij de verwerking moet hij afwijkingen en inconsistenties signaleren en tenslotte moet hij in voortdurende dialoog staan met de ma. nagementpositie, waarop de uitvoer van het MIS gericht is.

\section{De praktische betekenis van LIS en MIS}

In een andere publicatie (Management informatie en informatiemanagement) ben ik uitvoerig ingegaan op de praktische betekenis, welke het onderscheid tus. sen logistieke informatiesystemen en management informatiesystemen voor een grote organisatie kan hebben.

Reacties uit andere grote organisaties hebben mij gesterkt in mijn overtuiging dat niet alleen de kwaliteit van de informatiesystemen op zichzelf, maar vooral de organisatorische inpassing in de organisatie van beslissende betekenis is voor het effect van die informatiesystemen.

Zo is bij de N.V. Nederlandse Spoorwegen de rapportering over het lopende gebeuren aan de topleiding in omvang zeer sterk gereduceerd, maar tegelijkertijd toegespitst op de „key factors for success”, waardoor de kwaliteit is toegenomen.

Deze kwaliteitstoeneming kon overigens alleen bereikt worden, omdat het MIS op zijn beurt ook eisen aan het management stelde. De managers werden namelijk bij de gekozen aanpak gedwongen zich uit te spreken over de vraag welke zaken wèl en welke zaken niet belangrijk werden gevonden voor het goed functioneren van de onderneming. En van die belangrijk geachte zaken moest voorts worden aangegeven welke kwalitatieve en kwantitatieve doelen het management zichzelf m.b.t. deze zaken stelde. Tenslotte moest de consistentie tussen de verschillende doelen (op velerlei gebied) in het oog gehouden worden. De onder- 
steuning die het MIS aan het NS-management geeft heeft vooral betrekking op twee belangrijke managementfuncties, te weten planning en beheersing. Het gaat hierbij om beheersing van het lopende gebeuren en planning van het toekom. stige gebeuren. De winst van het MIS was een sterke reductie annex kwaliteits. verbetering van de informatie over het lopende bedrijfsgebeuren, waardoor meer tijd voor het topmanagement beschikbaar kwam om zich op het toekom. stige bedrijfsgebeuren te concentreren. Dat was in de zeventiger jaren ook hard nodig, o.m. gezien de vijf nu in aanbouw zijnde spoorlijnen (tussen 1934 en 1977 was er in Nederland niet één reizigersspoorlijn gebouwd!), die nu eenmaal erg veel voorbereiding vergen, op vele terreinen.

Ook in militaire organisaties heeft het door mij gemaakte onderscheid tussen logistieke problemen en managementproblemen weerklank gevonden. Desgevraagd vertelde men mij dat de logistieke problemen zich in het veld voordoen, op bataljonsniveau en daaronder.

Deze problemen verdienen grote aandacht; informatiesystemen kunnen daar. bij een ondersteunende rol spelen. Tegelijkertijd spelen op gevechtsgroep- en divisieniveau de problemen van het algemeen management, waarvoor óók maar andere - ondersteunende informatie vereist is. Ik ben ervan overtuigd dat de problematiek voor niet-militaire organisaties in wezen niet anders is.

\section{Literatuur}

Dale, Van, Groot woordenboek der Nederlandse taal, Den Haag, $1970^{9}$

Tieleman, T., Management informatie en informatiemanagement, Amsterdam/Brussel 1974

Tieleman, T., Organisatorische aspecten van management informatiesystemen

Proefschrift Technische Hogeschool Twente 1977

Winkler Prins, Grote Encyclopedie, Amsterdam/Brussel 1973 